\title{
Short Communication. Photochemical Reactions of Riboflavin: Covalent Binding to DNA and to Poly (dA) • Poly (dT)
}

\author{
JOHN F. ENNEVER ${ }^{(22)}$ AND WILLIAM T. SPECK ${ }^{(20)}$ \\ Department of Pediatrics, Rainbow Babies and Childrens Hospital, School of Medicine, Case Western Reserve \\ University, Cleveland, Ohio, USA
}

\section{Summary}

Standard phototherapy illumination of human cells in the presence of riboflavin is known to produce single-strand breaks in intracellular DNA. A new photochemical reaction is described between riboflavin and purified DNA in which an adduct is formed. Unlike the previously described oxygen-dependent reaction between light-activated riboflavin and deoxyguanosine, this new photochemical reaction is oxygen-independent and involves deoxyadenosine or thymidine.

\section{Abbreviations}

CPM, counts per minute

FAD, flavine adenine dinucleotide

FMN, flavin mononucleotide

SSC, standard saline citrate

The effectiveness of phototherapy in the treatment of neonatal jaundice is so well established and its usage so widespread that there is increasing concern about its overuse: particularly under circumstances where it is neither necessary nor beneficial $(9,10)$. Of special concern are the potential long-term hazards of this treatment regimen for the developing infant (1). Accordingly, our laboratory has been investigating the DNA-modifying activity of high intensity illumination with visible light in an attempt to better define the potential genetic consequences of phototherapy.

Riboflavin, a vitamin which as a component of the coenzymes FMN and FAD is ubiquitous to eukaryotic and prokaryotic cells, is photodecomposed in vitro by wavelengths of light considered by many to be optimal for the treatment of unconjugated hyperbilirubinemia (7). Evidence has accumulated to suggest that a similar photochemical reaction occurs in jaundiced infants receiving phototherapy $(4,12)$. Studies in our laboratory have determined that light-activated riboflavin modifies both purified and intracellular DNA (8). Furthermore, we have presented evidence that one type of photochemical reaction involves the photodecomposition of the deoxyguanosine moieties in the double helix and that this reaction is not dependent on the generation of singlet oxygen (3). The purpose of the present report is to extend these earlier observations $(3,8)$ by describing a new photochemical reaction between lightactivated riboflavin and DNA. Such studies permit a better understanding of the potential genetic hazards of phototherapy and may further the development of a phototherapy unit effective in the treatment of neonatal jaundice yet devoid of any serious untoward effects.

\section{MATERIALS AND METHODS}

The following chemicals and biochemicals were obtained from the indicated commercial supply houses and used without further purification: calf thymus DNA, Miles Laboratory (13); poly (dA). poly (dT), poly (dG)-poly (dC), DNase I (EC. 3.1.4.5), and riboflavin, Sigma Chemical Co. (14); D- $\left[2-{ }^{14} \mathrm{C}\right]$-riboflavin, Amersham (15); biochemical grade $\mathrm{CsCl}(99.9 \%)$, Gallard-Schlesinger Chemical Co. (16); toluene, trichloroacetic acid and high purity argon, Fisher Scientific Co. (17), Omnifluor, New England Nuclear (18).

DNA was dissolved in $1 / 10 \mathrm{SSC}(0.015 \mathrm{M} \mathrm{NaCl}, 0.0015 \mathrm{M}$ sodium citrate) at a concentration of $1 \mathrm{mg} / \mathrm{ml}$ and allowed to stand for at least $48 \mathrm{~h}$ at $4^{\circ} \mathrm{C}$ before use in order to assure complete dispersion. Poly $(\mathrm{dA}) \cdot$ poly $(\mathrm{dT})$ and poly $(\mathrm{dG}) \cdot$ poly $(\mathrm{dC})$ were dissolved in $1 / 10 \mathrm{SSC}$ at a concentration of $85 \mu \mathrm{g} / \mathrm{ml}$ and either used immediately or stored at $-20^{\circ} \mathrm{C}$. $\left[{ }^{14} \mathrm{C}\right]$-Riboflavin in $1 / 10$ SSC with a specific activity of $160 \mu \mathrm{Ci} / \mathrm{mg}$ was added to the DNA or copolymer solutions to give a final concentration of $10 \mu \mathrm{g} / \mathrm{ml}$.

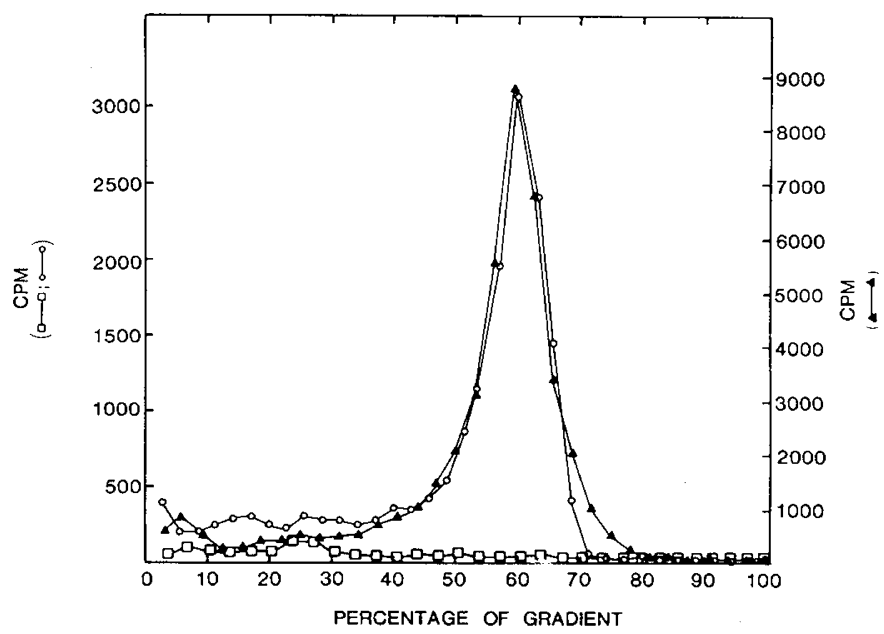

Fig. 1. Radioactivity profile of $\mathrm{CsCl}$ equilibrium gradients of DNAriboflavin. Purified DNA and D-[2- $\left.{ }^{14} \mathrm{C}\right]$-riboflavin were illuminated either aerobically $\left(\mathrm{O}_{-}\right)$) or anaerobically $(\boldsymbol{\Lambda}-\boldsymbol{\Delta})$ as described in "Materials and Methods." Radioactivity profile of control solution kept in dark before sedimentation is shown $(\square \square \square)$. Sedimentation was from left to right.

One-ml aliquots were placed on screw-capped, plastic flasks before illumination. Samples illuminated in an anaerobic environment were prepared by bubbling with argon for 2 min before sealing the flask. Illumination was carried out at a fluence of 150 $\mu \mathrm{W} / \mathrm{cm}^{2}$ (at $450 \mathrm{~nm}$ ) utilizing a standard phototherapy unit and a broad-spectrum fluorescent light source (Duro Test Vita Light) as described previously (3).

After illumination, samples were layered onto $4 \mathrm{ml}$ of $\mathrm{CsCl}$ (density $=1.79 \mathrm{~g} / \mathrm{cc}$ ) and centrifuged in a Beckman SW50 rotor at $30,000 \mathrm{rpm}(84,000 \times \mathrm{g}$, average $)$ for $40-48 \mathrm{~h}$ at $20^{\circ} \mathrm{C}$. The gradients were fractionated into 5-drop aliquots from the bottom of the gradient. Fractions were precipitated with $5 \%(\mathrm{w} / \mathrm{v})$ trichloroacetic acid and collected on Whatman glass fiber filters. 
Radioactivity was determined in a Nuclear Chicago Liquid Scintillation counter (19) utilizing toluene-based cocktail (Omnifluor).

All experiments were performed at least three times. Representative data are shown in the results.

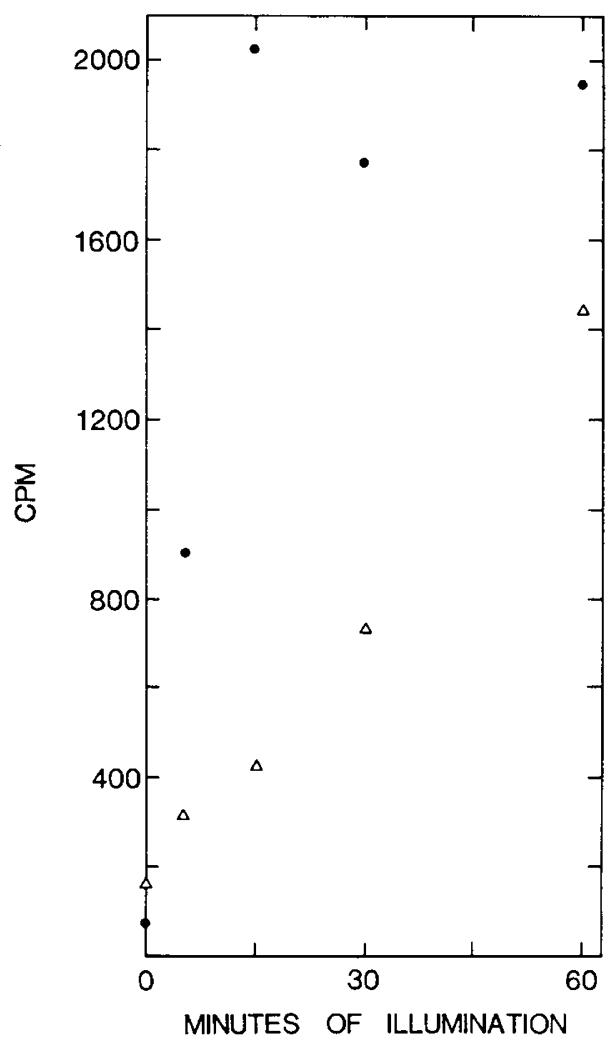

Fig. 2. Comparison of rate of DNA-riboflavin reaction under aerobic and anaerobic conditions. Identical solutions of DNA and D- $\left[2-{ }^{14} \mathrm{C}\right]-$ riboflavin were illuminated either aerobically $(\triangle)$ or anaerobically $(\bullet)$ for indicated times. Trichloroacetic acid precipitable radioactivity (CPM) vs time of illumination is plotted.

\section{RESULTS}

A solution of calf thymus DNA and $\left[{ }^{14} \mathrm{C}\right]$-riboflavin was illuminated with a standard phototherapy unit. The DNA was then sedimented to equilibrium in a self-generating $\mathrm{CsCl}$ gradient, and the radioactivity profile determined as described in "Materials and Methods." The result is shown in Figure l. In the gradient, a single band of radioactivity (from the labeled riboflavin) was observed. When a sample was similarly prepared but protected from light before sedimentation, no band of radioactivity was found in the resulting gradient (Fig. 1). Moreover, no band was observed in gradients of samples which were digested with DNase I after illumination and before centrifugation (not shown). These results suggest that the observed band of radioactivity in the $\mathrm{CsCl}$ gradient is due to the covalent binding of riboflavin (or at least a portion of the riboflavin containing the labeled carbon, C-2) to purified DNA.

The observed chemical reaction between light-activated riboflavin and DNA occurs both in the presence and in the absence of oxygen (Fig. 1). Moreover, the reaction occurs to a greater extent in an anaerobic environment ( $c f$. maximum CPM in aerobic and anaerobic samples in Fig. 1). This conclusion is strengthened by the results of the kinetic experiment shown in Figure 2. In this experiment identical samples were illuminated, one aerobically and the anaerobically. At various times, aliquots were removed and the total trichloroacetic acid-precipitable counts (i.e., DNAbound riboflavin) were determined. The results clearly show the reaction between riboflavin and DNA occurred more rapidly when illumination occurred under anaerobic conditions.

When solutions of $\left[{ }^{14} \mathrm{C}\right]$-riboflavin and either poly $(\mathrm{dA}) \cdot$ poly $(\mathrm{dT})$ or poly $(\mathrm{dG}) \cdot$ poly $(\mathrm{dC})$ were illuminated and sedimented in $\mathrm{CsCl}$, as was done with the DNA, the results shown in Figure 3 were obtained. Three bands of radioactivity were observed after the photoreaction between poly $(\mathrm{dA}) \cdot$ poly $(\mathrm{dT})$ and $\left[{ }^{14} \mathrm{C}\right]$-riboflavin. The buoyant densities of these three bands were $1.615 \mathrm{~g} /$ $\mathrm{cc}, 1.586 \mathrm{~g} / \mathrm{cc}$ and $1.558 \mathrm{~g} / \mathrm{cc}$. The buoyant density of native poly (dA) - poly (dT) in $\mathrm{CsCl}$ is 1.647 (11). In contrast, virtually no trichloroacetic acid-precipitable radioactivity is observed in samples of poly $(\mathrm{dG})$ - poly $(\mathrm{dC})$ illuminated in the presence of $\left[{ }^{14} \mathrm{C}\right]-$ labeled riboflavin. These results demonstrate the specificity of light-activated riboflavin for poly $(\mathrm{dA}) \cdot$ poly $(\mathrm{dT})$.

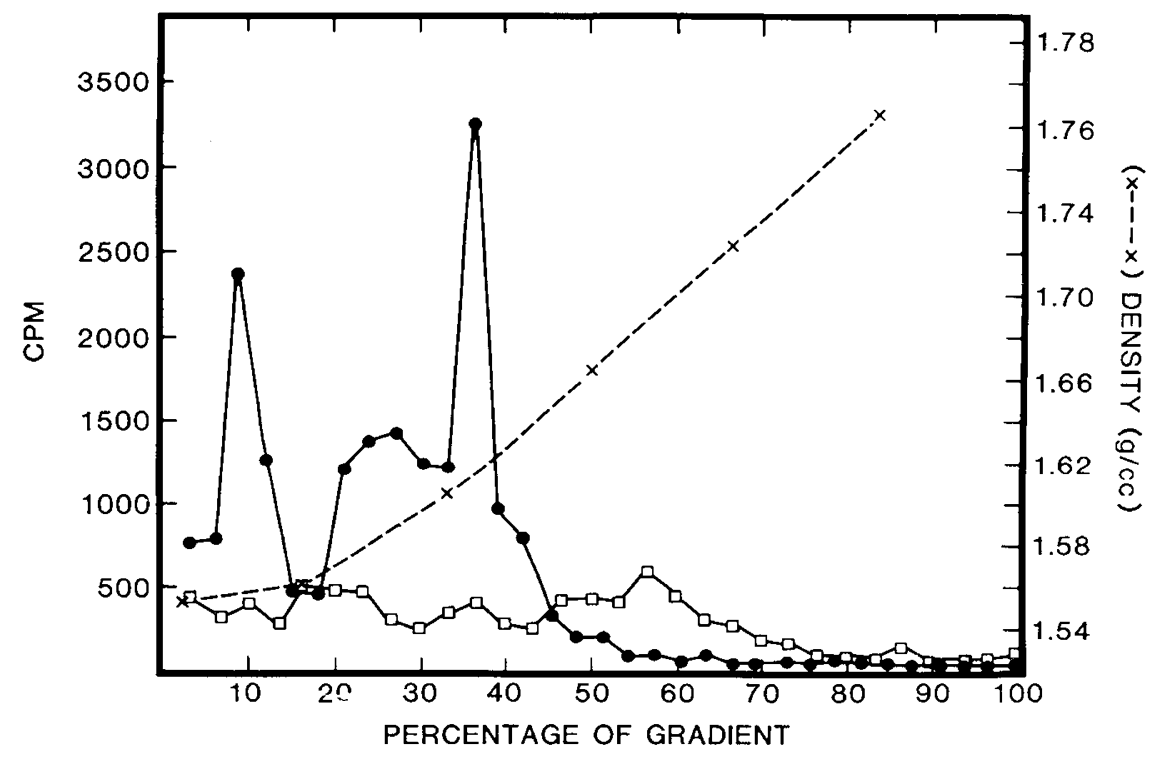

Fig. 3. Radioactivity profile of $\mathrm{CsCl}$ equilibrium gradients of copolymer-riboflavin photoproducts. Poly $(\mathrm{dA}) \cdot$ poly $(\mathrm{dT})$ and poly $(\mathrm{dG}) \cdot$ poly (dC) were illuminated aerobically for $60 \mathrm{~min}$ in the presence of $\mathrm{D}-\left[2-{ }^{14} \mathrm{C}\right]$ -riboflavin as described in "Materials and Methods." The plot of density vs gradient position with the scale to the right applies specially to the poly (dA) - poly (dT) gradient and was determined by gravimetric measurements on selected fractions. Sedimentation was from left to right. 


\section{DISCUSSION}

A new photochemical reaction between riboflavin and DNA has been described. Several observations suggest that binding of light-activated riboflavin to DNA is covalent, more specific: (1) the riboflavin remains associated with the DNA in the $\mathrm{CsCl}$ at equilibrium (approximately 8 molar $\mathrm{CsCl}$ ): conditions which abolish essentially all ionic interactions; (2) the radioactivity remains bound to the DNA after precipitation with trichloracetic acid; (3) the binding of the riboflavin to the DNA was unaltered by Sephadex column chromatography (2); and (4) no band of radioactivity was observed in gradients of samples which were digested with Dnase I after illumination and before centrifugation. Final proof for the existence of a covalent bond between riboflavin and DNA will require more extensive chemical analysis.

The photochemical reaction described in this report differs significantly from those previously reported. Early work in our laboratory demonstrated that of the four isolated deoxynucleosides found in DNA, light-activated riboflavin modified only deoxyguanosine and that this photochemical reaction was oxygen dependent (3). The present report described additional photochemical reaction between riboflavin and intact, purified DNA which is not oxygen dependent and results in the apparent covalent binding of riboflavin and/or a photodecomposition product of riboflavin to purified DNA. Moreover, the results observed with synthetic copolymers and riboflavin indicate that the covalent binding to DNA involves deoxyadenosine or thymidine.

Previous studies have shown that the intracellular DNA of eukaryotic cells can be damaged by illumination from standard phototherapy units $(5,6,8)$. The photochemical basis for these in vitro observations must be accurately defined in order to develop techniques to identify potential DNA modifications in jaundiced infants receiving phototherapy. The photochemical reaction described in this report is another potential mechanism for lightinduced damage to DNA. Clearly, phototherapy is a complex process, and the potential exists for serious long-term consequences in infants undergoing this treatment.

\section{REFERENCES AND NOTES}

I. Behrman, R. E., Brown, A. K., Currie, M. R. Hastings, J. W. Odell, G. B. Schaffer, R., Setlow, R. B., Vogel, T. P., Wurtman, R. J., Anderson, R. J.,
Kostkowski, H. J. and Simopoulos, A. P.: Preliminary report of the committee on phototherapy in the newborn infant. J. Pediatr., 84: 135 (1974).

2. Dixon, A. and Ennever, J. F.: (unpublished observations)

3. Ennever, J. F. and Speck, W. T.: Photodynamic reaction of riboflavin and deoxyguanosine. Pediatr. Res., 15: 956 (1981).

4. Gromisch, D. S., Lopez, R., Cole, H. S., and Cooperman, J. M.: Light (phototherapy) induced riboflavin deficiency in the neonate. J. Pediatr., 90: 118 (1977).

5. Santella, R. M., Rosenkranz, H. S., and Speck, W. T.: Intracellular deoxyribonucleic acid-modifying activity of intermittant phototherapy. J. Pediatr., 93: 106 (1978).

6. Sideris, E. G., Papageorgiou, G. C., Charalampous, S. C., and Vitsa, E. M.: A spectrum of response study on single strand DNA breaks, sister chromatid exchanges, and lethality induced by phototherapy lights. Pediatr. Res., 15: 1019 (1981).

7. Sisson, T. R. C., Salvin, B., and Hamilton, P. B.: The effect of broad and narrow spectrum fluorescent light on blood constituents. In: D. Bergsma, S. H. Blondheim: Bilirubin metabolism in the newborn. II. Excerpta Medica, Birth Defects-Original Article Series, Vol. 12, No. 2, pp. 122-133. (Elsevier-North Holland Publishing Co., New York, 1976).

8. Speck, W. T., Chen, C. C., and Rosenkranz, H. S.: In vitro studies of effects of light and riboflavin on DNA and HeLa Cells. Pediatr. Res., 9: 150 (1975).

9. Speck, W. T. and Rosenkranz, H. S.: Phototherapy for neonatal hyperbilirubinemia-a potential environmental health hazard to newborn infants. Environ. Mutagen. 1: 321 (1979).

10. Speck, W. T.: The case against phototherapy. In: D. H. Smith, R. A. Hoelkelman Controversies in Child Health and Pediatric Practice, pp. 383-401. (McGrawHill Book Co., New York, 1981).

11. Szybalski, W.: Use of cesium sulfate for equilibrium density gradient centrifugation. In: L. Grossman, K. Moldane: Methods in Enzymology, Vol. 12, Part B, pp. 330-360 (Academic Press, New York, 1968)

12. Tan, K. L., Chow, M. T., and Karim, S. M. M.: Effect of phototherapy on neonatal riboflavin status. J. Pediatr., 93: 494 (1978).

13. Elkhart, IN.

14. St. Louis, MO

15. Arlington Heights, IL.

16. Carle Place, NY.

17. Pittsburgh, PA.

18. Boston, MA.

19. Searle Analytic Inc., Fort Lee, NJ.

20. Dr. W. T. Speck is a Research Career Development Awardee of the National Cancer Institute (1KO-4-CA-0043).

21. The authors would like to acknowledge many helpful discussions with Dr. Herbert S. Rosenkranz and the assistance of Ms. Anne Vrana in the preparation of the manuscript.

22. Requests for reprints should be addressed to John F. Ennever, Ph.D., M.D. Department of Pediatrics, Rainbow Babies and Childrens Hospital, Case Western Reserve University, 2101 Adelbert Road, Cleveland, OH 44106 (USA).

23. This research was supported by National Cancer Institute grant CA-23692-04.

24. Received for publication June 2, 1981.

25. Accepted for publication June 26, 1982.

\section{ERRATUM}

The author regrets the following oversight in his article, "The Effects of Chronic Renal Failure in Infancy on Growth, Nutritional Status and Body Composition."

The equation on page 785 for the prediction of intracellular water should read:

$$
\mathrm{ICW}=3.0705-0.0674 \mathrm{ht}+0.00098 \mathrm{ht}^{2}(13)
$$

